DOI: https://doi.org/10.36477/tourismhospcee-1-9

УДК 338.486.2(477+100)

Міщук І. П.

доктор економічних наук, доцент, завідувач кафедри підприємництва, торгівлі та логістики

Львівського торговельно-економічного університету ORCID: https://orcid.org/0000-0001-5661-0164

Головата $\mathbf{P}$.

магістр

Львівського торговельно-економічного університету

Mishchuk Ihor, Holovata Ruslana

Lviv University of Trade and Economics

\title{
ТУРИСТИЧНІ ПІДПРИЕМСТВА УКРАЇНИ В СИСТЕМІ МІЖНАРОДНОЇ ТУРИСТИЧНОЇ ДІЯЛЬНОСТІ
}

\section{TOURIST ENTERPRISES OF UKRAINE IN THE SYSTEM OF INTERNATIONAL TOURIST ACTIVITY}

\begin{abstract}
Розглянуто теоретико-методичні засади дослідження міжнародної туристичної діяльності підприємства. Висвітлено сутність та уточнено поняття туристичної діяльності. На статистичних матеріалах висвітлено роль міжнародної туристичної діяльності в економічі країни та економічні критерії доцільності розвитку туризму. Виявлено наявність сутнісних суперечностей у підходах вчених до визначення поняття «туристична діяльність», через наукову полеміку запропоновано авторське формулювання даної дефініиії. Розглянуто сутність і різноманіття трактувань науковою спільнотою поняття «ринок туристичних послуг», термінів «туристична послуг» $i$ «туристичний продукт», надано пропозиції щеоо авторського тлумачення категорій «ринок туристичних послуг», «туристична послуга» і систематизації їх видового різноманіття. Розкрито функиії та особливості туристичного підприємства в умовах глобалізації.
\end{abstract}

Ключові слова: туристична діяльність, туристичне підприємство, туристичні послуги, туристичний продукт, функиії туристичного підприємства, система міжнародної туристичної діяльності.

Рассмотрены теоретико-методические основы исследования международной туристической деятельности предприятия. Освещена сущность и уточнено понятие туристической деятельности. На статистических материалах освещены роль международной туристической деятельности в экономике страны и экономические критерии целесообразности развития туризма. Выявлено наличие сущнностных противоречий в подходах ученых к определению понятия «туристическая деятельность», через научную полемику предложена авторская формулировка данной дефиниции. Рассмотрены сущность и многообразие трактовок научным сообществом понятия «рынок туристических услуг», терминов «туристическая услуг» и «туристический продукт», даны предложения по авторскому толкованию категорий «рынок туристических услуг», «туристическая услуга» и систематизачии их видового разнообразия. Раскрыты функичии и особенности туристического предприятия в условиях глобализачии.

Ключевые слова: туристическая деятельность, туристическое предприятие, туристические услуги, туристический продукт, функции туристического предприятия, система международной туристической деятельности.

The article considers the theoretical and methodological principles of the study of international tourist activity of the enterprise. The aim of the article is to study and clarify on the basis of critical logical and semantic analysis of the essence of the concepts "tourist activity», "tourist enterprise», disclosure of functions and features of tourist enterprise in globalization conditions and quantitative assessment of development of these enterprises in Ukraine. According to the results of the analysis, the essence and the concept of tourist activity are clarified. Based on statistical materials highlighted the role of international tourism in the country's economy and economic criteria for the development of tourism. The presence of essential contradictions in the approaches of scientists to the definition of the concept of «tourist activity» is revealed, through scientific controversy the author's formulation of this definition is offered. The essence and variety of interpretations by the scientific community of the concept of «market of tourist services», the terms "tourist services» and «tourist product》, are considered, given offers on the author's interpretation of the categories "market of tourist services», "tourist service» and systematization of their species diversity. Proposed to interpret the market of tourist services as a sphere of economic relations between producers, intermediaries and consumers of tourist services. The peculiarities of tourist enterprises in comparison with other enterprises in the system of domestic economy are revealed, the functions and peculiarities of the tourist enterprise in the conditions of globalization are generalized. The analysis of the basic approaches to systematization of spe- 
cies diversity of tourist enterprises and typology of functions of separate categories of tourist activity participants is carried out. The objectivity of differentiation of species diversity of functions of travel agents and tour operators, conditioned by the leading position of tour operators in the system "producer of a tourist product-intermediaryconsumery is substantiated. The results of quantitative assessment of the processes of development of tourist enterprises in Ukraine are reflected.

Keywords: tourist activity, tourist enterprise, tourist services, tourist product, functions of tourist enterprise, system of international tourist activity.

Постановка проблеми. Швидкий розвиток глобалізаційних процесів сприяв зростанню мобільності населення планети, спрямованій як на цілі пошуку більш вигідного місця праці та життєдіяльності, так і з метою розширення світогляду, задоволення культурних, духовних та інших потреб за допомогою туристичних подорожей. Цьому сприяло також і послаблення візових режимів країн світу, які прагнуть заробляти на туристах. Очікуване в умовах поступового подолання пандемії відновлення світової економіки логічно передбачає перспективи зростання потоків туристів та урізноманітнення видів туризму. Це, своєю чергою, формує передумови для розвитку міжнародної туристичної діяльності підприємств в різних країнах світу, а також суб'єктів туристичної інфраструктури, які супроводжують процес надання туристичних послуг. В Україні актуальність і пріоритетність розвитку туризму підтверджується чинною Стратегією розвитку туризму та курортів на період до 2026 року, в якій вказано, що розвиток туристичної діяльності «...сприяє підвищенню рівня зайнятості, диверсифікації національної економіки, збереженню і розвитку культурного потенціалу, збереженню екологічно безпечного навколишнього природного середовища, а також підвищує рівень інноваційності національної економіки» [1].

Разом 3 тим, туристична діяльність вітчизняних підприємств гальмується або ускладнюється багатьма чинниками внутрішнього та зовнішнього середовища, а також недостатністю розробки науково-теоретичної бази та повноцінного комплексу методичних підходів і практикоорієнтованих рекомендацій щодо організації діяльності суб'єктів туристичного бізнесу.

Аналіз останніх досліджень і публікацій. Питання формування теоретико-методологічних основ функціонування туристичних підприємств були предметом дослідження багатьох вітчизняних і зарубіжних вчених, серед яких: В. АлієваБарановська, Я. Алмашій, Р. Балашова, М. Біржаков, Т. Божидарнік, М. Бойко, В. Брич, Т. Городня, I. Дахно, В. Джинджоян, Р. Драпушко, Є. Драчова, Л. Дядечко, Ю. Забаєв, М. Кляп, Ф. Шандор, Н. Коніщева, М. Мальська, Ю. Масюк, С. Мельниченко, Н. Міценко, Т. Незвещук-Когут, А. Парфіненко, О. Савіцька, Т. Сокол, Т. Ткаченко, І. Школа, Ю. Юхновська, С. Goeldner, R. McIntosh та ін.
Значна частина досліджень пов'язана 3 визначенням ролі туризму, суб'єктів туристичної діяльності, результатів їх функціонування у вигляді показників розвитку туризму в окремих країнах, однак, обмежена кількість наукових праць стосується безпосередньо діяльності туристичних підприємств, ідентифікації їх сутнісно-критеріальних ознак, функцій та особливостей діяльності. Таким чином, питання створення передумов та розвитку туристичної діяльності вітчизняних підприємств потребують активізації уваги дослідників. Це зумовлює актуальність обраної теми статті.

Недосконалість чинної науково-теоретичної бази розвитку туристичної діяльності суб'єктів господарювання України в питаннях сутнісного змісту, ролі та особливостей міжнародної туристичної діяльності туристичних підприємств, систематизації видового різноманіття та типологізації функцій окремих категорій учасників туристичної діяльності, зумовлюють потребу в проведенні аналізу теоретико-методичних засад розвитку туристичних підприємств у системі міжнародної туристичної діяльності.

Основною метою статті $є$ виклад результатів дослідження та уточнення на підставі критичного логіко-змістового аналізу сутності понять «туристична діяльність», «туристичне підприємство», розкриття функцій та особливостей туристичного підприємства в умовах глобалізації та кількісна оцінка процесів розвитку зазначених підприємств в Україні.

Виклад основного матеріалу дослідження. Розгортання глобалізаційних процесів наприкінці XX - на початках XXI століття в поєднанні з послабленням візових режимів країн світу та зростанням мобільності населення в більшості країн світу сприяли зростанню потоків туристів та урізноманітненню видів туризму, який останнім часом став розглядатися як вид господарської діяльності, що здатна приносити прибутки. Як свідчить світова статистика, у 2019 р. подорожі та туризм забезпечили внесок у світовий валовий внутрішній продукт в обсязі 9258,3 млрд дол. США, що на 21,0 \% більше в порівнянні 3 показником 2016 р. (середньорічні темпи приросту склали 6,6 \%). Завдяки цьому частка даного сектора у світовому ВВП зросла на $0,3 \%$ - до рівня 10,4 \%. Яскравим свідченням привабливості досліджуваного сегмента економіки є також зростання інвестицій в сектор туризму на $23,7 \%$ проти 2016 року, а також залучених працівників - на 7,0 \% (табл. 1). 
Роль туризму в розвитку економіки світу в 2016-2019 роках

\begin{tabular}{|c|c|c|c|c|c|c|c|}
\hline \multirow{2}{*}{ Показники } & \multicolumn{4}{|c|}{ Роки } & \multirow{2}{*}{ Відхилення } & \multirow{2}{*}{$\begin{array}{l}\text { Динаміка, } \\
\%, 2019 \text { р. } \\
\text { до 2016 p. }\end{array}$} & \multirow{2}{*}{$\begin{array}{c}\text { Середньо- } \\
\text { річні темпи } \\
\text { росту, \% }\end{array}$} \\
\hline & 2016 & 2017 & 2018 & 2019 & & & \\
\hline $\begin{array}{l}\text { Внесок подорожей та туризму в } \\
\text { світовий ВВП, млрд дол. США }\end{array}$ & 7650,2 & 8240,7 & 8811,0 & 9258,3 & 1608,1 & 121,0 & 106,6 \\
\hline $\begin{array}{l}\text { Частка подорожей та туризму } \\
\text { в світовому ВВП, \% }\end{array}$ & 10,1 & 10,3 & 10,4 & 10,4 & 0,3 & - & - \\
\hline $\begin{array}{l}\text { Чисельність зайнятих у сфері } \\
\text { туризму, тис. чол }\end{array}$ & 117336 & 119627 & 122891 & 125595 & 8259 & 107,0 & 102,3 \\
\hline $\begin{array}{l}\text { Капіталовкладення в туризмі, } \\
\text { млрд. дол. США }\end{array}$ & 806,6 & 879,9 & 940,9 & 997,4 & 190,8 & 123,7 & 107,3 \\
\hline
\end{tabular}

Джерело: складено авторами за [2]

Економічні вигоди країни від розвитку туристичної діяльності проявляються через зростання зайнятості (робочі місця в галузі туризму та суміжних галузях), особистих (заробітна плата працівників туристичної та суміжних галузей, доходи власників), комерційних (валові надходження, що створюються завдяки витратам туристів, чистий прибуток підприємств туристичної та суміжних галузей) і державних (податки, збори, доходи державних підприємств) доходів, надходжень іноземної валюти i, завдяки цьому, - підвищення частки туризму у формуванні валового внутрішнього продукту [3]. Наукова спільнота стверджує, що для розвитку національної економіки сфера туризму виступає як:

- інструмент наповнення бюджету країни та зростання іiі валового внутрішнього продукту;

- механізм приваблення та притоку іноземної валюти в країну;

- засіб підвищення інвестиційної привабливості країни як для іноземних, так і для внутрішніх інвесторів;

- сектор розвитку підприємництва (особливо - малого та мікропідприємництва) i, тим самим, важіль формування середнього класу в суспільстві;

- сфера активного створення нових робочих місць та підвищення рівня зайнятості населення як безпосередньо у наданні туристичних послуг, так i в пов'язаних видах діяльності суб'єктів туристичної інфраструктури; - сектор економіки, покликаний забезпечувати можливості для відтворення робочої сили людини та їі оздоровлення [4-10].

Зважаючи на це, в Україні протягом 1985-2019 pр. було прийнято досить велику кількість нормативно-правових актів, що регулюють діяльність у сфері туризму, які окреслили основні напрямки та перспективи розвитку туристичної діяльності підприємств України. Проте, проведений критичний аналіз сформованої при цьому нормативно-правової бази туристичної діяльності свідчить, що вона потребує суттєвої модернізації, оскільки іiі поточний стан не відповідає сучас- ним правовим та адміністративним рішенням, які діють у світовій туристичній сфері. Так, зокрема, як в нормативно-правових актах України, так і в навчальній та науковій літературі існує проблема співвідношення (i необхідності розмежування) термінів «туризм» та «туристична діяльність», попри їх широке використання як у законодавстві України, так і в практичній діяльності та наукових публікаціях [11].

Вивчення літературних джерел показало, що серед вчених відсутня одностайність в розумінні сутності туристичної діяльності. Так, Л. Дядечко ототожнює поняття «туристична діяльність» та «підприємницька діяльність в туризмі» і зазначає, що «...головна мета підприємництва в туризмі полягає в розробленні маршрутів, формуванні туристичних потоків за обраними маршрутами, у виробництві туристичних товарів і наданні туристичних послуг, комплектуванні туристичного продукту відповідно до попиту споживачів 3 вигодою (прибутком) для себе» [6].

Натомість, Ф. Шандор і М. Кляп розглядають туристичну діяльність як «професійну, трудову діяльність працівників сфери туризму» [7]. Подібну точку зору (розгляд туристичної діяльності як виду професійної діяльності працівника, що має відповідні компетентності) підтримує і Т. Г. Сокол, стверджуючи, що: «Туристична діяльність це ... сфера праці, де виробляється та реалізується на ринку туристичний продукт і організується його споживання - обслуговування туристів під час подорожі» [8, с. 118].

М. Б. Біржаков розглядає туристичну діяльність як «...соціальну активність людей, які працюють в туристичній сфері, мають певний соціальний статус у відповідності до посади, яку вони займають, і соціальну роль, що охоплює сукупність посадових обов'язків і службових функцій» [4]. 3 іншого боку, даний науковець вважає туризмом і безпосередню діяльність туриста, тобто мандрівку з чітко окресленими туристичними цілями, і туристичну діяльність - діяльність з організації та здійснення (супроводу) таких мандрівок [4, с. 22]. 
На наш погляд, своєрідною «точкою опори» для вирішення даної дилеми має бути визначення Всесвітньої Туристичної Організації, яка розглядає туризм як подорож у вільний час та один 3 видів активного відпочинку, а туристичну діяльність - як виробничо-сервісну діяльність, метою якої є надання туристичних послуг та організація подорожей [12].

Сутність туристичної діяльності можна конкретизувати через такі змістові складові:

1) туристична діяльність $є$ різновидом господарської діяльності, що здійснюється суб'єктами господарювання 3 метою отримання прибутку. Відповідно до Закону України «Про туризм» туристичну діяльність в країні здійснюють туристичні оператори (туроператори) та туристичні агенти (турагенти). При цьому туристичні оператори повинні мати статус юридичної особи, займатися винятково туристичною діяльністю (створенням і реалізацією туристичного продукту, наданням туристичних послуг) та мати ліцензію на туроператорську діяльність. Натомість, турагентами можуть виступати як підприємства (юридичні особи), так і фізичні особи-підприємці, які виконують роль посередника між туроператорами та туристами у реалізації туристичного продукту та діють на основі агентського договору;

2) туристична діяльність туроператорів і турагентів дозволяє задовольняти потреби у рекреації, оздоровленні, саморозвитку, самозбагаченні, культурні та духовні потреби споживачів туристичних послуг;

3) туристична діяльність пов'язана 3 наданням особливого виду послуг - туристичних - через створення та реалізацію особливого товару туристичного продукту; реалізація туристичного продукту на ринку туристичних послуг означає визнання суспільством цього специфічного товару і дозволяє суб'єктам туристичної діяльності отримувати доходи і відшкодовувати витрати на його створення, просування та реалізацію;

4) суб'єкти туристичної діяльності здійснюють їі постійно і на професійних засадах з метою отримання прибутку через задоволення потреб споживачів у туристичних послугах;

5) особливості організації надання туристичних послуг, права та обов'язки, відповідальність сторін формалізуються у відповідних договорах: на туристичне обслуговування, готельне обслуговування, екскурсійне обслуговування, ваучерах.

Зважаючи на вищезазначене, вважаємо, що туристична діяльність - це діяльність суб'єкта господарювання 3 метою отримання прибутку шляхом надання туристичних послуг та реалізації туристичного продукту споживачам для задоволення їх рекреаційних, оздоровчих, пізнавальних та інших потреб, що провадиться на професійній основі на підставі ліцензії.
М. Бондаренко звертає увагу на те, що «забезпечення туристичної діяльності потребує таких обов'язкових елементів, як туристична послуга та ринок туристичних послуг» [13, с. 21]. При цьому даний автор трактує «ринок туристичних послуг» як сукупність соціально-економічних взаємовідносин $з$ метою задоволення потреб туристичного потоку i реалізації потенціалу ланцюга туристичної пропозиції у процесі трансформації туристичного продукту в грошовий еквівалент та інтеграції у світовий простір [там же]. На наш погляд, зазначений ринок потрібно трактувати дещо ширше - як сферу економічних взаємовідносин між продуцентами, посередниками і споживачами туристичних послуг. Своєю чергою, О. Гарбера визначає туристичну послугу як «сегмент сфери послуг, спрямований на задоволення потреб споживачів туристичного продукту на підставі продажу певного туристичного ресурсу» $[14$, c. 87]. В той же час, Т. Сокол вказує, що «...туристична послуга частіше за все виступає у формі корисного ефекту праці, а не матеріального продукту» [8, с. 119], виокремлюючи послуги 3 розміщення, харчування, транспортне й екскурсійне обслуговування, спортивно-оздоровче, культурно-видовищне, побутове обслуговування та ін.

Велике різноманіття надаваних у межах туристичної діяльності послуг зумовлює потребу в їх систематизації за такими класифікаційними ознаками, запропонованими науковцями $[13$, с. $21 ; 15]$, як форма надання, характер послуги, спосіб іiі оплати, територія, спеціалізація, форма організації, тривалість, способи надання, частота, сегмент ринку, функціональне призначення, вплив на пропозицію, тривалість споживання, характер споживання, сутність туризму (обов'язковість послуги), вплив на конкурентоспроможність продуцента та ін.

Туристична галузь, як відзначає Н. Моiсеєва, «створює туристичні послуги, формує туристичний продукт і здійснює його реалізацію, активно використовуючи маркетингові комунікації» $[10$, c. 32$]$. Принциповою особливістю туристичного продукта $€$ те, що він $є$ попередньо (завчасно, наперед) розробленим комплексом туристичних послуг (не менше двох, в т.ч. послуги перевезення, розміщення та інші туристичні послуги), що реалізується або пропонується для реалізації за визначеною ціною. При цьому з точки зору виробництва, наголошує Н. Сагалакова, туристичний продукт є сукупністю певної кількості та якості товарів і послуг переважно рекреаційного характеру, підготовлених у даний конкретний момент для реалізації споживачам; це потенційна можливість, абстрактний споживчий продукт, що складається з благ, джерела яких знаходяться у природі як у матеріальній (туристичні товари, споруди, інфраструктура), так і в нематеріальній (послуги, середовище, кліматичні умови) формі 
[16, с. 29]. Отже, туристичний продукт порівняно 3 туристичною послугою $є$ ширшим поняттям і його головні характеристики як об'єкта виробництва в туристичній діяльності полягають в тому, що це:

- сукупність туристичних послуг, які дозволяють задовольнити потреби та інтереси туриста (споживача туристичного продукту);

- до його складу можуть входити як матеріальні (товари), так і нематеріальні (послуги) елементи;

- комплексне використання пропонованих у складі туристичного продукту послуг та формування відповідних умов їх споживання дозволяє в повній мірі задовольнити попит споживача.

Таким чином, туристичний продукт виступає як результат економічної діяльності туристичного підприємства, який на ринку туристичних послуг пропонується потенційним споживачам та набуває вартості і споживчої вартості.

Головними суб'єктами туристичного ринку, що здійснюють туристичну діяльність, є туристичні підприємства. Вивчення літературних джерел дозволило узагальнити основні підходи до визначення поняття «туристичне підприємство» в табл. 2. Як видно, у трактуванні сутності туристичного підприємства відсутня одностайність. Н. Моісеєва пропонує під туристичним підприємством розуміти будь-який суб'єкт туристичної діяльності, що $\epsilon$ юридичною особою чи фізичною особоюпідприємцем (ФОП), які створюють комплексний туристичний продукт та/або надають характерні та супутні туристичні послуги $[10$, с. 26$]$. Вважаємо, що такий підхід суперечить сутності підприємства за Господарським кодексом України, оскільки фізична особа-підприємець не може виступати юридичною особою (підприємством).

В. Брич звертає увагу на те, що туристичні підприємства як суб'єкти господарювання характеризуються тим, що вони: мають свою індустрію виробництва і надання послуг туристам; $€$ певним способом його функціонування через самостійність у прийнятті рішень, застосуванні власних ініціатив для реалізації підприємницьких ідей; $\epsilon$ формою організації життєдіяльності особи і суспільства загалом; виготовляють туристичні послуги та товари; просувають туристичний продукт до споживачів; пов'язують інтереси суспільства, власника, колективу, працівника; є сферою створення дешевих робочих місць; - поєднуються майже 3 усіма видами економічної діяльності $[5$, c. 78$]$.

Проте, на нашу думку, туристичне підприємство не є формою життєдіяльності ні особи, ні суспільства, оскільки як самостійний суб'єкт господарювання функціонує з метою задоволення потреб власників та отримання прибутку. Сумнівним є розгляд туристичного підприємства і як сфери створення дешевих робочих місць, оскільки провадження туристичної діяльності на рівні міжнародних стандартів потребує спеціальної фахової підготовки, володіння іноземними мовами, високого рівня освіченості, тобто високого рівня кваліфікації персоналу туристичних підприємств та ін. Це підтверджують дані статистики: і в 2016 р., і в 2019 році серед працівників туристичних підприємств України частка осіб з вищою та середньою спеціальною освітою в галузі туризму була досить високою - понад 40,0 \% [22] (рис. 1).

Незважаючи на те, що в Законі України «Про туризм» визначається зміст та суб'єкти туристичної діяльності, чіткого визначення сутності туристичного підприємства тут не знаходимо. Згідно Закону, підприємства, що здійснюють туристичну діяльність, можуть виступати туроператорами або турагентами. При цьому не визнаються суб' єктами туристичної діяльності, а відтак - туристичними підприємствами, ті «підприємства, які надають лише послуги 3 організації відвідувань об'єктів культури, відпочинку та розваг, лише послуги транспортування туристів або тільки реалізують сувенірну продукцію, згідно діючого законодавства...» $[15$, с. 140$]$. Таким чином, потребує уточнення власне питання віднесення тих чи інших суб'єктів до категорій туроператорів або турагентів. Підставою для цього вважаємо такі сутніснокритеріальні ознаки:

- для підприємства-туроператора: наявність статусу юридичної особи відповідно до Господарського кодексу України; першочергова орієнтація на діяльність 3 організації та створення туристичного продукту, а також 3 надання туристичних послуг; спроможність надавати як характерні, так і супутні послуги; наявність ліцензії на провадження туроператорської діяльності.

- для підприємства-турагента: наявність статусу юридичної особи відповідно до Господарського кодексу України; виокремлення в якості основної посередницької діяльності 3 реалізації туристичних продуктів, розроблених туроператорами; здатність виступати посередником під час реалізації як характерних, так і супутніх послуг.

За даними державної служби статистики України, упродовж 2016-2019 рр. кількість туристичних підприємств зросла на 1,6 \% (табл. 3) і склала 1867 од, в тому числі туроператори - 368 од, турагенти - 1259 од., суб'єкти, що здійснюють екскурсійну діяльність - 70 од (рис. 2). При цьому кількість туроператорів дещо зменшилася (на 14 од), а турагентів - зросла (на 37 од).

Загальна чисельність працівників туристичних підприємств зросла в 2019 році порівняно 3 2016 роком на 575 чол або $6,7 \%$ і склала 9120 чол.

Виходячи 3 пропозицій Т. Незвещук-Когут [27], можна виділити такі особливості туристичних підприємств порівняно з іншими підприємствами у системі вітчизняної економіки: 
Таблиця 2

Підходи до визначення поняття «туристичне підприсмство»

\begin{tabular}{|c|c|}
\hline Автор, джерело & Характеристика підходу \\
\hline $\begin{array}{l}\text { Н. Моісеєва } \\
{[10, \text { с. } 26]}\end{array}$ & $\begin{array}{l}\text { будь-який суб’єкт туристичної діяльності, що є юридичною особою чи фізичною особою- } \\
\text { підприємцем (ФОП), які створюють комплексний туристичний продукт та/або надають } \\
\text { характерні та супутні туристичні послуги }\end{array}$ \\
\hline $\begin{array}{l}\text { I. Школа } \\
{[9, \text { с. } 112]}\end{array}$ & $\begin{array}{l}\text { виробничі підприємства різних форм власності (державні, приватні, товариства } \\
\text { з обмеженою відповідальністю, акціонерні товариства тощо), які виробляють } \\
\text { туристичні товари і послуги для громадян }\end{array}$ \\
\hline $\begin{array}{l}\text { Р. Балашова } \\
{[17, \text { с. } 46]}\end{array}$ & $\begin{array}{l}\text { самостійний суб’єкт господарювання в туристичній галузі, створений компетентним } \\
\text { органом державної влади або органом місцевого самоврядування, або іншими суб’єктами, } \\
\text { як конкурентоспроможна підпиємницька структура для задоволення суспільних потреб у } \\
\text { туристичних послугах шляхом здійснення туристичної діяльності згідно із об’єктивними } \\
\text { законами суспільного, економічного та державного розвитку та в порядку, передбаченому } \\
\text { кодексами та законами України }\end{array}$ \\
\hline $\begin{array}{l}\text { Т. Незвещук-Когут } \\
{[18, \text { с. } 6]}\end{array}$ & $\begin{array}{l}\text { суб'єкти господарювання, де виробляються, реалізуються та споживаються туристичні } \\
\text { продукти та послуги, пов'язані з організацією туристичних подорожей, оздоровлення та } \\
\text { відпочинку для людей, які тимчасово перебувають за місцем постійного проживання }\end{array}$ \\
\hline $\begin{array}{l}\mathrm{M} \\
{[1 \mathrm{C}}\end{array}$ & $\begin{array}{l}\text { системний комплекс факторів виробництва, який здійснює процес виробництва і } \\
\text { реалізації туристичних продуктів для свого відтворення як видової господарської одиниці }\end{array}$ \\
\hline $\begin{array}{l}\text { К. Пілігрім } \\
{[20, \text { с. } 138] .}\end{array}$ & $\begin{array}{l}\text { суб’єкт господарської діяльності, який використовує найману працю, метою діяльності } \\
\text { якого є отримання прибутку від надання споживачу якісних туристичних послуг і } \\
\text { товарів, що відноситься до одного з видів готельного типу, або спеціалізованого засобу } \\
\text { розміщення, або виступає на туристичному ринку туроператором або турагентом, які } \\
\text { мають статус юридичної особи та персонал у штаті }\end{array}$ \\
\hline $\begin{array}{l}\text { Г. Горіна } \\
{[21, \text { с. } 47]}\end{array}$ & $\begin{array}{l}\text { під туристичним підприємством пропонується розуміти будь-яких юридичних та } \\
\text { фізичних суб’єктів туристичної діяльності, які створюють та/або надають характерні та } \\
\text { супутні туристські послуги та комплексний туристський продукт }\end{array}$ \\
\hline $\begin{array}{l}\text { В. Брич } \\
{[5, \text { с. } 92]}\end{array}$ & $\begin{array}{l}3 \text { позицій системного сприйняття туризму, (ТП) - це системний комплекс факторів } \\
\text { виробництва, який здійснює процес виробництва і реалізації туристичних продуктів } \\
\text { для свого відтворення як видової господарської одиниці; з позиції менеджменту - це } \\
\text { організований колектив, який забезпечений матеріальними і фінансовими засобами і має } \\
\text { здійснювати діяльність для задоволення потреб туристів, з характерною внутрішньою } \\
\text { структурою, який самостійно приймає стратегічні й тактичні рішення, спрямовані на } \\
\text { отримання прибутку. }\end{array}$ \\
\hline
\end{tabular}

Джерело: узагальнено авторами

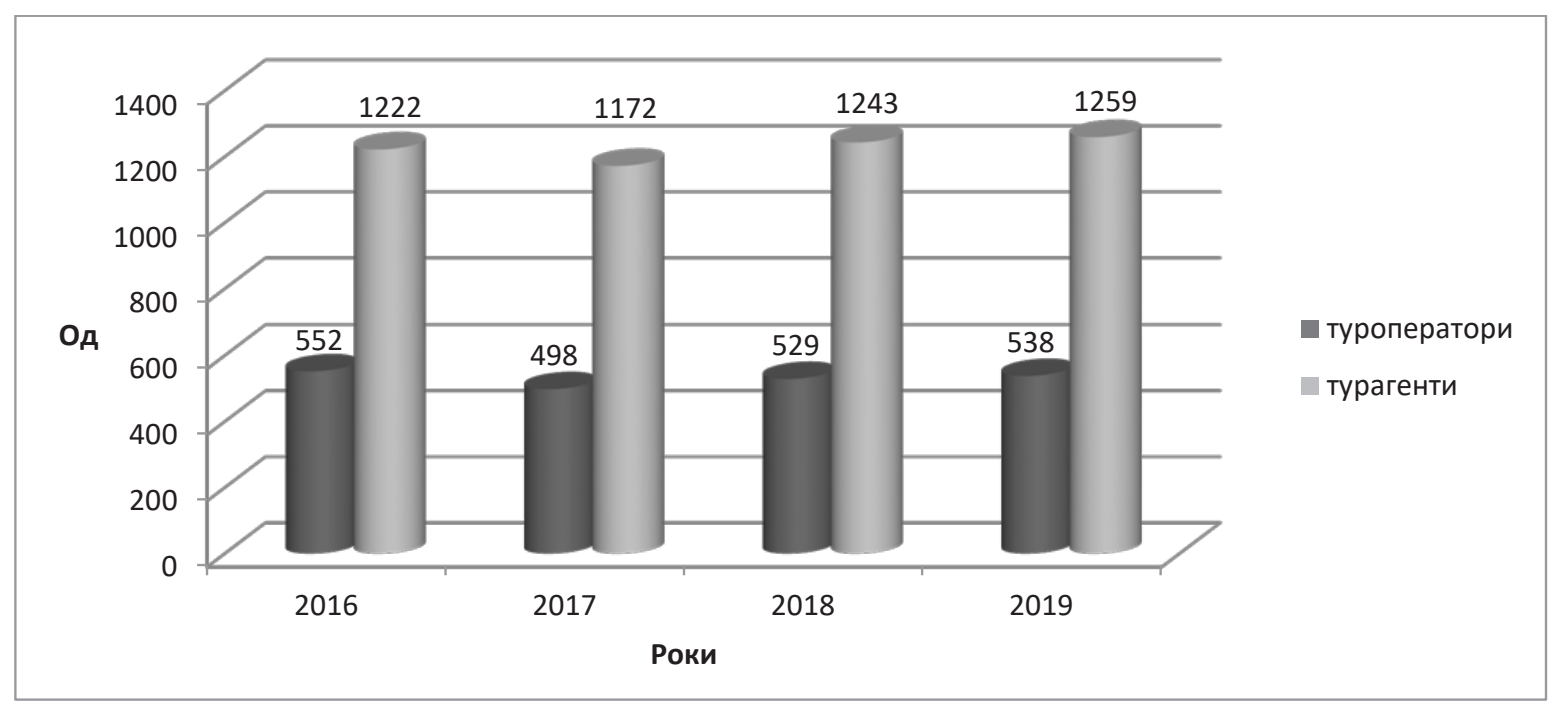

Рис. 1. Динаміка кількості туристичних підприємств в Україні в 2016-2019 роках

Джерело: побудовано авторами за [22] 
Таблиця 3

Кількість туристичних підприємств та працівників в них в Україні в 2016-2019 роках

\begin{tabular}{|c|c|c|c|c|c|c|}
\hline \multirow{2}{*}{ Показники } & \multicolumn{4}{|c|}{ Роки } & \multirow{2}{*}{ Відхилення } & \multirow{2}{*}{$\begin{array}{l}\text { Динаміка, \% } \\
2019 \text { до } 2016\end{array}$} \\
\hline & 2016 & 2017 & 2018 & 2019 & & \\
\hline Кількість туристичних підприємств, од & 1838 & 1743 & 1833 & 1867 & 29 & 101,6 \\
\hline \multicolumn{7}{|l|}{ В Т.Ч. } \\
\hline - кількість туроператорів & 552 & 498 & 529 & 538 & -14 & 97,5 \\
\hline - кількість турагентів & 1222 & 1172 & 1243 & 1259 & 37 & 103,0 \\
\hline $\begin{array}{l}\text { - кількість суб'єктів, що здійснюють } \\
\text { екскурсійну діяльність }\end{array}$ & 64 & 73 & 61 & 70 & 6 & 109,4 \\
\hline Чисельність працівників, чол & 8545 & 8190 & 8934 & 9120 & 575 & 106,7 \\
\hline
\end{tabular}

Джерело: складено авторами за [22]

- діяльність туристичних підприємств пов'язана 3 виробництвом і споживанням специфічного туристичного продукту, що обумовлює iii цільову спрямованість на задоволення потреб конкретного споживача, значну фондо- та трудомісткість; значний вплив на формування попиту на туристичні послуги здійснюють економічні, політичні, соціальні та екологічні чинники; існування суттєвої диференціації попиту на туристичні послуги, що обумовлена диференціацією контингентів туристів за різними ознаками; неспівпадіння пропозиції та споживання туристичних послуг у часі та просторі; обмеженість процесу надання туристичних послуг в часі; нерозривність виробництва та споживання туристичних послуг, неможливість збереження послуг; залежність діяльності туристичних підприємств від сезонних коливань, природно-кліматичних умов; унікальність і комплексність послуг як фактори конкурентоспроможності туристичного продукту; залежність якості туристичних послуг від виконавця та від рівня мотивації персоналу туристичного підприємства та ін.

Особливості туристичних підприємств нерозривно пов'язані 3 виконуваними ними функціями, базовий перелік яких відображений в позиції В. Брича, згідно з якою основними функціями туристичного підприємства є:

- маркетингова функція - передбачає широке застосування маркетингових досліджень та реклами з визначення місткості потенційних ринків туристичного продукту;

- функція інноваційного менеджменту - сприяє появі нових послуг (продукту), привабливих як для туристів, так і для інвесторів;

- функція інформаційного менеджменту дозволяє удосконалювати за допомогою інформаційних технологій швидке просування туристичного продукту [5, с. 82-83].

Разом 3 тим, заслуговує на увагу пропозиція щодо виокремлення серед функцій туристичного підприємства комплектуючої функції турагента (комплектація туру з окремих послуг (для рецептивного туроператора), комплектація комбінованих турів із рецептивних турів (для ініціативного туроператора), комплектація турів 3 певними видами послуг (для турагентів)), сервісної (обслуговування туристів на маршрутах, в офісі під час продажу пакетів турів) та гарантійної (надання туристам гарантій щодо туристичних послуг, що були раніше оплачені в обумовленій кількості) [23].

На нашу думку, функції, виконувані туроператорами та турагентами, дещо відрізняються, адже туроператор переважно здійснює оптовий продаж туристичних продуктів, тоді як турагент - роздрібний. В такому випадку потрібно визнати, що комплектувальна функція туроператора охоплює дослідження та сегментацію туристичного ринку, створення туристичного продукту, кадрове забезпечення процесу надання туристичних послуг, формування та розвиток господарських зв'язків 3 турагентами та ін. Необхідність сервісної функції обумовлена такими операціями, як: формування пакету туристичних послуг, укладання угод 3 господарюючими суб'єктами туристичної інфраструктури; надання візового, страхового, фінансового супроводу туриста, рекламування та інформування потенційних споживачів про особливості туристичного продукту. Гарантійна функція реалізується через гарантування високої якості надаваних туристичних послуг, постійний моніторинг стану споживання туристичного продукту та туристичної послуги, компенсацію непередбачуваних втрат, тощо.

Туристичне підприємство-турагент теж виконує комплектувальну функцію, однак, вона пов'язана 3 наповненням туристичного пакету комплексом послуг, а також забезпеченням їх надання суб'єктами туристичної інфраструктури системою укладених угод, формуванням системи господарських зв'язків з туроператорами та їх підтриманням в актуальному стані, комплектацією туристичного пакету за рахунок туристичних продуктів різних туроператорів та ін. Оскільки турагент виступає на ринку туристичних послуг посередником, йому притаманні інформаційні та збутові функції. Інформаційна функція включає інформування потенційних споживачів про особливості пропонованого туристичного продукту, надання консультативної допомоги в організації 


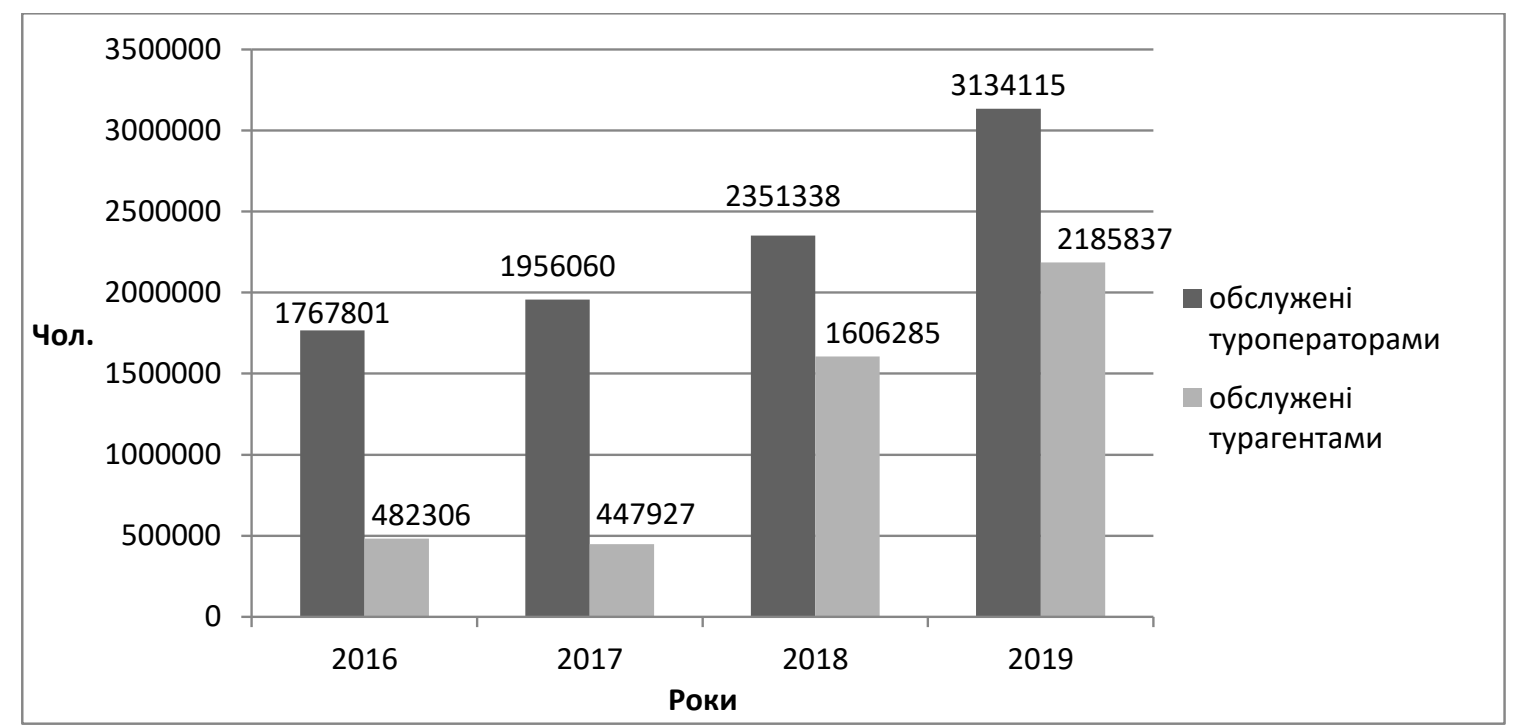

Рис. 2. Чисельність туристів, обслужених туристичними підприємствами України, в 2016-2019 роках

Джерело: побудовано авторами за [22]

подорожі, маркетингові комунікації в соціальних мережах та розповсюдження рекламно-інформаційної продукції, ін. Пропонуючи на туристичному ринку туристичні продукти різних туроператорів, турагент виконує збутову функцію, спрямовану на представлення на ринку цих продуктів, безпосередній продаж туристичних продуктів, постійний моніторинг стану споживання туристичного продукту та туристичної послуги та ін. Таким чином, в якості туристичних підприємств на ринку туристичних послуг виступають, перш за все, туроператори і турагенти, забезпечуючи формування пропозиції туристичних продуктів потенційним споживачам та здійснюючи їх реалізацію і контроль споживання.

Моніторинг динаміки чисельності обслужених в системі міжнародної туристичної діяльності туристів туристичними підприємствами України за 2016-2019 рр. (рис. 2) показує лідерство туроператорів, що є цілком виправданим, оскільки туроператори є виробниками туристичної продукції та виступають надійними гарантами 3 продажу послуг $[24$, c. 73$]$. Як видно, протягом усього періоду чисельність туристів зростала, досягши максимальних показників у 2019 р., коли туроператори обслужили 3134115 туристів, а турагенти - 2185837 туристів. Порівняно 32016 роком туроператори збільшили чисельність споживачів туристичних послуг на $77,3 \%$, а турагенти - у 4,5 рази.

На жаль, в 2020-2021 рр. пандемія коронавірусу неочікувано і катастрофічно ускладнила поступальний розвиток вітчизняних туристичних підприємств [25], що зумовлює потребу в пошуку нових, адаптованих до постковідної економіки інструментів та механізмів розвитку системи міжнародного туризму.

Висновки і перспективи подальших досліджень. Забезпечення сталого розвитку туристичного підприємства та його діяльності потребує покладання в основу управлінських рішень, особливо, стратегічних, результатів глибокого аналізу його функціонування. Одним 3 можливих напрямів подальших досліджень в даному контексті вважаємо посилення моніторингу та удосконалення методик аналізу діяльності туристичних підприємств, зокрема - шляхом розробки ефективних алгоритмів дослідження ї міжнародної туристичної діяльності.

\section{Список використаних джерел:}

1.Стратегія розвитку туризму та курортів на період до 2026 року. URL: https://www.kmu.gov.ua/npas/249826501

2. Мировой Атлас Данных. Туризм. URL: https://knoema.ru/atlas/topics/\%D0\%A2\%D1\%83\%D1\%80\%D0\%B8\% $\mathrm{D} 0 \% \mathrm{~B} 7 \% \mathrm{D} 0 \% \mathrm{BC}$

3. Методика розрахунку обсягів туристичної діяльності : Наказ Держтурадміністрації України та Держкомстату України від 12.11.2003 р. № 142/394. URL: http://zakon4.rada.gov.ua/laws/show/z1128-03/page

4. Биржаков М. Б. Введение в туризм / М. Б. Биржаков. М.-СПб. : «Издательский Дом ГЕРДА», НП «Издательство «Невский Фонд», 2014. 544 с.

5.Брич В. Я. Організація туризму : підручник / За заг. ред. д.е.н., проф. В. Я. Брича. Тернопіль : ТНЕУ, 2017. $448 \mathrm{c}$. 
6. Дядечко Л. П. Економіка туристичного бізнесу : навч. посіб. Київ : Центр учбової літератури, 2007.224 с.

7.Шандор Ф. Ф., Кляп М. П. Сучасні різновиди туризму : підручник. Київ : Знання, 2013. 334 с. (Вища освіта XXI століття). URL: https://westudents.com.ua/glavy/93345-41-turistichna-dyalnst.html

8. Сокол Т. Г. Основи туристичної діяльності : підручник / Під ред. проф. Орлова В. Ф. Київ : Грамота, 2004.327 с.

9. Школа I. М. Розвиток туристичного бізнесу регіону : монографія / за ред. Школи I. М. Чернівці : Книги -XXI, 2007. $292 \mathrm{c}$.

10.Моісєєва Н. І. Інноваційність туристичної сфери в умовах сталого розвитку: стратегічний вимір : дис. ... доктора екон. наук : 08.00.05. Харків, 2019. 523 с.

11.11 Опанасюк Н. А. Поняття туристичної діяльності: практико-правові аспекти визначення. Бюлетень Міністерства юстиції України. 2014. № 10. С. 92-102.

12.Tourism 2020 Vision. URL: http://www.unwto.org/facts/eng/vision.html

13.Бондаренко М. П. Теоретичні засади розвитку індустрії туризму. Економічний часопис-XXI. 2012. № 3-4. C. $19-22$.

14.Гарбера О. Є. Організація туристичної діяльності в системі світового ринку послуг. Економіка та держава. 2010. № 10. С. $86-89$.

15.Козубова Н. В. Туристичні послуги як об’єкт ринкових відносин в Україні. Інноваційна економіка. 2014. № 2. C. 137-143.

16. Сагалакова Н. О. Характеристика туристичного продукту як специфічного об'єкту ціноутворення. Iнвестиuіï: практика та досвід. 2015. № 17. С. 27-33.

17.Балашова Р. І. Методичні особливості сутності, поняття і характерних рис туристичного підприємства. Економіка промисловості. 2008. № 3. С. 38-47.

18.Незвещук-Когут Т. С. Удосконалення управління діяльністю туристичних підприємств : дис. ... канд. екон. наук : 08.00.04. Херсон, 2012. 195 с.

19.Бойко М. Г., Михайліченко Г. І. Економіко-предметне обгрунтування розвитку термінологічного апарату туризму. Економіка та держава. 2010. № 3. С. 47-49.

20.Пілігрім К. І. Особливості розвитку туристичних підприємств із урахуванням ролі персоналу та його мотивації. Торгівля, комериія, підприємництво. 2014. Вип. 17. С. 135-140.

21.Горіна Г. О. Сутність та особливості типології туристичних підприємств як суб'єктів управління. Науковий вісник Міжнародного гуманітарного університету. 2016. Вип. 20. С. 46-49. (Сер. Економіка і менеджмент).

22.Офіційний сайт Державної служби статистики України. URL: http://www.ukrstat.gov.ua

23. Алмашій Я. I. Теоретико-методологічні засади ефективної діяльності туризму в сучасній ринковій економіці. Вісник Чернівецького торговельно-економічного інституту. 2012. Вип. 2. URL: http://tourlib.net/statti ukr/almashij.htm

24.Мельниченко С., Зікій Н. Туристичні підприємства України: виклики реальності. Вісник КН̈ТЕУ. 2019 . № 3. C. $70-84$.

25.Барна М. Ю., Табака Н. М. Діяльність туристичної галузі у пандемійний та постпандемійний період. Сучасні напрями розвитку економіки, підприємництва, технологій та їх правового забезпечення : матер. міжнар. наук.-практ. конф. Львів : вид-во ЛТЕУ, 2020. С. 173-174.

\section{References:}

1. Strategy for the development of tourism and resorts for the period up to 2026 (Strateghija rozvytku turyzmu ta kurortiv na period do 2026 roku) [Online], available at: https://www.kmu.gov.ua/npas/249826501

2. World Data Atlas. Tourism (Mirovoj Atlas Dannyh. Turizm) [Online], available at: https://knoema.ru/atlas $/$ topics $/ \%$ D0\%A2\%D1\%83\%D1\%80\%D0\%B8\%D0\%B7\%D0\%BC

3. Methods of calculating the volume of tourist activity: Order of the State Tourism Administration of Ukraine and the State Statistics Committee of Ukraine dated 12.11.2003 № 142/394 (Metodyka rozrakhunku obsjaghiv turystychnoji dijaljnosti : Nakaz Derzhturadministraciji Ukrajiny ta Derzhkomstatu Ukrajiny vid 12.11.2003 r. № 142/394) [Online], available at: http://zakon4.rada.gov.ua/laws/show/z1128-03/page

4. Byrzhakov M. B. (2014), Vvedenie v turizm (Introduction to tourism), M.-SPb. : «Izdatel'skij Dom GERDA», NP «Izdatel'stvo «Nevskij Fond», 544 p.

5. Brych V. Ja. (2017), Organization of tourism: a textbook (Orghanizacija turyzmu : pidruchnyk), edited by Doctor of Economics, Prof. Brich V. Ya. Ternopil: TNEU, 448 p.

6. Djadechko L. P. (2007), Economics of tourism business: textbook (Ekonomika turystychnogho biznesu : navch. posib). Kyiv: Center for Educational Literature, 224 p.

7. Shandor F. F. and Kljap M. P. (2013), Modern varieties of tourism: a textbook (Suchasni riznovydy turyzmu : pidruchnyk). Kyiv: Knowledge, 334 p. (Higher education of the XXI century), available at: https://westudents.com.ua/ glavy/93345-41-turistichna-dyalnst.html

8. Sokol T. Gh. (2004), Fundamentals of tourism: a textbook (Osnovy turystychnoji dijaljnosti : pidruchnyk), edited by prof. Orlova V. F., Kyiv: Gramota, 327 p.

9. Shkola I. M. (2007), Development of tourist business in the region: a monograph (Rozvytok turystychnogho biznesu reghionu : monoghrafija), edited by Shkola I. M., Chernivtsi: Books - XXI, 292 p.

10. Moisjejeva N. I. (2019), Innovation of the tourism sector in terms of sustainable development: a strategic dimension: dis. ... Doctor of Economics. Sciences: 08.00.05 (Innovacijnistj turystychnoji sfery v umovakh stalogho rozvytku: strateghichnyj vymir: dys. ... doktora ekon. nauk : 08.00.05), Kharkiv, 523 p. 
11. Opanasjuk N. A. (2014), The concept of tourist activity: practical and legal aspects of definition (Ponjattja turystychnoji dijaljnosti: praktyko-pravovi aspekty vyznachennja), Bulletin of the Ministry of Justice of Ukraine, no. 10, pp. 92-102.

12. Tourism 2020 Vision [Online], available at: http://www.unwto.org/facts/eng/vision.html

13.Bondarenko M. P. (2012), Theoretical principles of tourism industry (Teoretychni zasady rozvytku industriji turyzmu), Economic Journal-XXI, no. 3-4, pp. 19-22.

14. Gharbera O. Je. (2010), Organization of tourist activity in the system of the world market of services (Orghanizacija turystychnoji dijaljnosti v systemi svitovogho rynku poslugh), Economy and State, no. 10, pp. 86-89.

15.Kozubova N. V. (2014), Tourist services as an object of market relations in Ukraine (Turystychni poslughy jak objekt rynkovykh vidnosyn v Ukrajini), Innovative economy, no. 2, pp. 137-143.

16. Saghalakova N. O. (2015), Characteristics of tourist product as a specific object of pricing (Kharakterystyka turystychnogho produktu jak specyfichnogho objektu cinoutvorennja), Investments: practice and experience, no. 17, pp. 27-33.

17. Balashova R. I. (2008), Methodical features of the essence, concepts and characteristics of a tourist enterprise (Metodychni osoblyvosti sutnosti, ponjattja i kharakternykh rys turystychnogho pidpryjemstva), Economics of Industry, no. 3, pp. 38-47.

18. Nezveshhuk-Koghut T. S. (2012), Improving the management of tourist enterprises: dis. ... cand. econ. Science: 08.00.04 (Udoskonalennja upravlinnja dijaljnistju turystychnykh pidpryjemstv: dys. ... kand. ekon. nauk: 08.00.04), Kherson, 195 p.

19.Bojko M. Gh. and Mykhajlichenko Gh. I. (2010), Economic and subject substantiation of the development of the terminological apparatus of tourism (Ekonomiko-predmetne obghruntuvannja rozvytku terminologhichnogho aparatu turyzmu), Economy and State, no. 3, pp. 47-49.

20.Pilighrim K. I. (2014), Peculiarities of development of tourist enterprises taking into account the role of staff and its motivation (Osoblyvosti rozvytku turystychnykh pidpryjemstv iz urakhuvannjam roli personalu ta jogho motyvaciji), Trade, commerce, entrepreneurship, no. 17, pp. 135-140.

21.Ghorina Gh. O. (2016), The essence and features of the typology of tourist enterprises as subjects of management (Sutnistj ta osoblyvosti typologhiji turystychnykh pidpryjemstv jak subjektiv upravlinnja), Scientific Bulletin of the International Humanities University, no. 20, pp. 46-49. (Ser. Economics and Management).

22. Official site of the State Statistics Service of Ukraine (Oficijnyj sajt Derzhavnoji sluzhby statystyky Ukrajiny) [Online], available at: http://www.ukrstat.gov.ua

23.Almashij Ja. I. (2012), Theoretical and methodological principles of effective tourism in the modern market economy (Teoretyko-metodologhichni zasady efektyvnoji dijaljnosti turyzmu v suchasnij rynkovij ekonomici) [Online], Bulletin of the Chernivtsi Trade and Economic Institute, no. 2, available at: http://tourlib.net/statti_ukr/almashij.htm

24.Meljnychenko S. and Zikij N. (2019), Tourist enterprises of Ukraine: challenges of reality (Turystychni pidpryjemstva Ukrajiny: vyklyky realjnosti), Visnyk KNTEU, no. 3, pp. 70-84.

25.Barna M. Ju. and Tabaka N. M. (2020), Activity of the tourist industry in the pandemic and post-pandemic period (Dijaljnistj turystychnoji ghaluzi u pandemijnyj ta postpandemijnyj period), Modern directions of economic development, entrepreneurship, technologies and their legal support: mater. international scientific-practical conf., Lviv: LTEU Publishing House, pp. 173-174. 